УДК 346.5

DOI https:// doi.org/10.32837/yuv.v0i1.2090

\author{
Л. Кожура, \\ кандидат юридичних наук, доцент, \\ заступник директора \\ Юридичного інституту \\ Київського національного економічного університету імені Вадима Гетьмана
}

\title{
ОСОБЛИВОСТІ ПРАВОВОГО РЕГУЛЮВАННЯ СФЕРИ АКВАКУЛЬТУРИ В УКРАЇНІ
}

Постановка проблеми. Сфера аквакультури належить до провідної сфери сільського господарства. Саме тому правове регулювання суспільних відносин, що виникають у зв'язку зі штучним розведенням об'єктив аквакультури та виробництво, реалізація сільськогосподарських кормів з переробки об'єктів аквакультури та ін. повинні бути належним чином нормативно урегульовані.

Мета статті - здійснення аналізу окремих законів України, якими урегульовано відносини у сфері аквакультури, та актуалізація недоліків правового регулювання досліджуваної сфери.

Стан дослідження. Окремі питання правового регулювання сфери аквакультури в Україні були предметом дослідження: В.Г. Бодрова, О.М. Сафронова, Н.І. Балдич, В.П. Галушко, А.В. Завірюхи, Л.В. Діброви, А.Д. Діброви, В.М. Геєць, С.В. Кваши, Н.М. Вдовенко, І.І. Лукінов, П.Т. Саблука, С.І. Алимова та інших.

Виклад основного матеріалу. Аквакультура існує вже не одне тисячоліття; ця галузь розвивалася поступово, 3 опорою на традиційні знання та завдяки допитливості фермерів, їхньої діяльності щодо задоволення потреб, їх позитивного досвіду, узагальнення та аналізу помилок і спільної діяльності. Вона росла протягом багатьох століть і інтегрувалася в природне, соціальне, економічне та культурне середовище. У XX-XXI століттях під впливом нау- ково-технічного прогресу в аквакультурі відбулися значні зміни. Сектор зростає безпрецедентними темпами і нині поставляє більше половини світового обсягу риби для споживання людиною (Source) [1].

Однак розвиток сфери аквакультури має і несприятливі наслідки для навколишнього середовища на місцевому, регіональному і глобальному рівнях. Це і соціальні конфлікти між користувачами земельних і водних ресурсів (особливо води), і недостача важливих екосистемних послуг. Крім того, останнім часом діяльність у галузі аквакультури викликає стурбованість і суперечливу реакцію з боку громадськості; особливо у зв'язку $з$ непродуманим вибором ділянок для аквакультури; знищенням середовища проживання (наприклад, мангрових заростей); використанням шкідливих хімічних речовин і ветеринарних препаратів; впливом втікачів з аквакультури на природні популяції; неефективним або нестійким виробництвом рибного борошна і риб'ячого жиру; а також соціальними і культурними проблемами працівників підприємств аквакультури і спільнот [1].

Здійснивши комплексний аналіз зазначених негативних тенденцій та проблем сфери аквакультури, вважаємо, що вирішення таких проблем можливе лише шляхом системного нормативного урегулювання аквакультури в Україні, визначення напрямів аквакультури, окреслення послуг, що можуть надаватися у цій сфері 
та ін. Саме тому дослідимо систему нормативно-правових актів, якими урегульовано відносини в досліджуваній сфері, та акцентуємо увагу на окремих правових колізіях.

У словниковій літературі під поняттям «аквакультура» прийнято розуміти штучне вирощування водних організмів, включаючи риб, молюсків, ракоподібних і водні рослини. Штучне вирощування передбачає втручання в розвиток організмів з метою збільшення їх виробництва, наприклад, регулярне поповнення запасів, годування, захист від хижаків і т.д. Крім того, вона має на увазі, що за культивовані популяції, планування, розвиток і експлуатацію систем, ділянок, підприємств аквакультури і застосовувані методи, а також за виробництво і транспортування відповідає окрема особа або підприємство [1].

Аквакультура (рибництво) - це сільськогосподарська діяльність із штучного розведення, утримання та вирощування об'єктів аквакультури у повністю або частково контрольованих умовах для одержання сільськогосподарської продукції (продукції аквакультури) та іï реалізації, виробництва кормів, відтворення біоресурсів, ведення селекційно-племінної роботи, інтродукції, переселення, акліматизації та реакліматизації гідробіонтів, поповнення запасів водних біоресурсів, збереження іх біорізноманіття, а також надання рекреаційних послуг [2].

Слід відзначити, що в низці нормативно-правових актів [3; 4; 2] такі поняття, як «рибництво» та «аквакультура», на думку законодавця, мають однаковий зміст та ототожнюються. Однак у правовій науці наявні точки зору щодо розмежування цих понять. Так, наприклад, О.В. Бойко у своєму дисертаційному дослідженні відзначає, що змістове навантаження таких понять $є$ різним і тому ї не можна ототожнювати. Так, поняття «рибництво» більш широке за своїм змістом та включає у себе як аквакультуру, так і марикультуру. Саме тому для розкриття змісту другого головного елементу структури рибного господарства - рибництва необхідно дослідити його зміст та виділити підвиди [5, с. 43]. Стосовно висловленої точки зору ми вважаємо, що поняття «аквакультура» та "рибництво» все ж таки $€$ тотожними поняттями, однак відсутність у нормативно-правових актах однакового підходу законодавця до вживання такого поняття спричиняє плутанину та їх підміну, що, на нашу думку, є недопустимим та спричиняє порушення правил юридичної техніки щодо однозначного трактування юридичних понять.

Термін «аквакультура» грецького походження (аква - вода, культура розвиток, вирощування, утворення). Головною метою аквакультури $є$ розведення та вирощування водних організмів (гідробіонтів). На сьогодні цілком можна говорити про те, що аквакультура проходить бурхливий розвиток.

Аквакультура розв'язує низку важливих питань, головними з яких $€$ : 1) отримання харчової продукціï та сировини для промисловості; 2) вирощування кормових компонентів для сільськогосподарських тварин; 3) вирощування рибопосадкового матеріалу для задоволення потреб ставового рибництва, рибальства, спортивного лову, акваріумістики; 4) очищення водойм та стоків від органічних та неорганічних залишків; 5) поліпшення якості води питних, рекреакційних та технічних водойм [5].

Найбільш поширеним об'єктом аквакультури $є$ риба. Вивченням риб займається наука іхтіологія (іхтіос риба, логос - наука). Вона вивчає зовнішні ознаки і внутрішню будову риб, ix взаємозв'язки із зовнішнім середовищем, розвиток риб, історію розвитку виду, роду, родини, ряду, географічне поширення риб. Іхтіологія також вивчає закономірності в коливанні чисельності риб, розробляє методи обліку і прогнозування виловів. 
Залежно від методів розведення та вирощування гідробіонтів розрізняють три типи аквакультури: 1) інтенсивна аквакультура - це розведення та вирощування гідробіонтів в умовах, де застосовуються комбікорми та спеціальні пристрої; 2) екстенсивна аквакультура - це розведення та вирощування гідробіонтів у неконтрольованих умовах, де застосовуються виключно природні корми; 3) напівінтенсивна аквакультура - це розведення та вирощування гідробіонтів, що передбачає частково контрольовані умови та підкормку. Такий вид аквакультури посідає проміжне місце між інтенсивною та екстенсивною аквакультурою.

Водночас залежно від способу вирощування, розмноження, розведення, утримання водних біоресурсів аквакультура поділяється на такі підвиди, як: а) випасна аквакультура - діяльність 3 екстенсивного вирощування об'єктів аквакультури шляхом вселення різновікових груп гідробіонтів, одержаних в умовах аквакультури, в рибогосподарські водні об'єкти (їх частини) для підвищення ефективності використання ї біопродукційного потенціалу; б) ставкова аквакультура - діяльність з розведення, утримання та вирощування об'єктів аквакультури 3 використанням рибницьких ставків, штучно створених водойм (руслових, балочних або одамбованих ставків), відокремлених від материнських водних об'єктів (ïх частин), лиманів, обводнених торфових кар’єрів тощо [6, с. 18]; в) індустріальна аквакультура - діяльність зі штучного розведення, утримання та вирощування об'єктів аквакультури 3 використанням рибницьких і плавучих садків, рибницьких басейнів, інших технологічних пристроїв, у тому числі із застосуванням установок замкнутого водопостачання [2].

Водночас залежно від форми рибогосподарської діяльності у сфері аквакультури остання може здійснюватися 3 використанням природних кормових ресурсів рибогосподарських водних об'єктів (їх частин) без застосування засобів інтенсифікації (екстенсивна аквакультура); вирощування об'єктів аквакультури здійснюється 3 використанням ущільнених посадок з інтенсивною штучною годівлею комбікормами, збалансованими за складом відповідно до біологічних потреб конкретних гідробіонтів, та іншими кормами з високою поживністю (інтенсивна аквакультура) та із застосуванням окремих засобів інтенсифікації, у тому числі з обмеженою штучною підгодівлею кормами різної поживності (напівінтенсивна аквакультура).

Н.М. Вдовенко, досліджуючи особливості функціонування сфери аквакультури, акцентує увагу на необхідності посилення державних заходів впливу i насамперед фінансово-кредитних і податкових інструментів у виробництві продукції аквакультури. Іншою важливою стороною, яка не досить вивчена у контексті розвитку аквакультури, є співвідношення між штучно вирощеною продукцією і продукцією, отриманою з дикої природи, та формування у цьому контексті політики імпортозаміщення морської риби продукцією, вирощеною у контрольованих людиною умовах. Є також практичні проблеми, пов'язані з організацією власного кормовиробництва, забезпеченістю рибницькою технікою, побудовою системи масового виробництва молоді риб, невизначеністю ведення аквакультури в умовах оренди гідротехнічних споруд та неврегульованості взаємин у цій сфері [7].

Також авторка наголошує на необхідності врахування критеріїв зональності розміщення об'єкта аквакультури та відповідно особливостей регіону.

Звернемо увагу на відсутність норм, які урегульовують окремі питання. Так, акцентуємо увагу, що в Законі України «Про аквакультуру» (далі - Закон) відсутні положення 
щодо порядку здійснення контролю та нагляду. Ст. 16 Закону є бланкетною та відсилає до Закону Украіни «Про ветеринарну медицину» щодо порядку проведення ветеринарно-санітарного контролю. Натомість у самому Законі відсутні норми, що визначають здійснення інших видів контролю (наприклад, контроль за поданням суб'єктами аквакультури звітної інформації щодо обсягів виробництва продукції аквакультури; контроль за діяльністю суб'єктів аквакультури під час розведення та/або вирощування чужорідних та немісцевих видів гідробіонтів тощо).

Водночас відзначимо, що норми Закону не містять положень щодо інших форм контрольної діяльності уповноважених суб'єктів: моніторингу, аудиту, нагляду, перевірок тощо. Відсутність засобів управлінської природи у спеціальному нормативно-правовому акті створюють ситуацію нівелювання окремих норм.

Прогалиною вбачається також відсутність норми, що встановлює право громадських інспекторів здійснювати громадський контроль за законністю провадження аквакультури як самостійного виду сільськогосподарської діяльності, наприклад, здійснення громадського контролю щодо дотримання норм Зон аквакультури (рибництва) та рибопродуктивності по регіонах України чи контроль за дотриманням законодавства суб'єктами аквакультури тощо. На нашу думку, є доречним доповнити норми Закону України «Про аквакультуру» ст. «Громадський контроль за аквакультурою». А функціональні повноваження громадського інспектора (контролера) визначити окремим розділом у Положенні про громадського інспектора рибоохорони.

Окрім здійснення контрольно-наглядової діяльності, також варто акцентувати увагу на здійсненні дозвільно-реєстраційної діяльності у сфері аквакультури уповноваженими суб’єктами. Зокрема, цим
Законом не урегульовано питання отримання дозволів (дозволу на спеціальне водокористування; дозволу на вилучення водних біоресурсів тощо) та здійснення реєстраційної діяльності (об’єктів аквакультури, напрямів аквакультури тощо).

Відповідно до Закону одним із напрямів аквакультури є товарна аквакультура - діяльність, що проводиться 3 метою одержання товарної продукції аквакультури та іiі подальшої реалізації. Втім ні Законом України «Про аквакультуру», ні іншими нормативноправовими актами не визначено шляхи реалізації продуктів аквакультури. Так, на нашу думку, законодавцю варто акцентувати увагу та визначити порядок реалізації продуктів аквакультури. Зокрема, пропонуємо визначити шляхи реалізації залежно від статусу суб'єкта: а) для суб'єктів державного сектору; б) для суб'єктів приватного сектору; в) для експорту.

Окремим недоліком Закону хотілося б виокремити відсутність положень, що визначають взаємодію суб'єктів аквакультури між собою; взаємодію публічних органів управління та суб'єктів господарювання, які здійснюють аквакультуру; взаємодію між громадськими органами та органами публічного управління; взаємодію між громадськими органами та суб'єктами господарювання, які здійснюють аквакультуру. На нашу думку, питанню взаємодіiі повинен бути присвячений окремий розділ у Законі, адже до суб'єктів публічного управління віднесено: Кабінет Міністрів України; центральний орган виконавчої влади, що забезпечує формування державної політики у сфері рибного господарства; центральний орган виконавчої влади, що реалізує державну політику у сфері рибного господарства; місцеві державні адміністраціі; органи місцевого самоврядування; громадські інституціï; фізичні та юридичні особи. Таким чином, чисельність зазначених суб'єктів є дуже широкою, а взаємодія між ними потребує законодавчого урегулювання. 
У изій статmі розкрито особливості правового регулювання аквакультури.

Акценттовано увагу, що в Законі України "Про аквакультуру» (далі - Закон) відсутні положення щодо порядку здійснення контролю та нагляду. Ст. 16 Закону $е$ бланкетною та відсилає до Закону України «Про ветеринарну медиичину» щзодо порядку проведення ветеринарно-санітарного контролю. Натомість у самому Законі відсутні норми, що визначають здійснення інших видів контролю (наприклад, контроль за поданням суб'єктами аквакультури звітної інформації щзодо обсягів виробництва продукиіï аквакультури; контроль за діяльністю суб'єктів аквакультури під час розведення та/або вирошування чужорідних та немісиевих видів гідробіонтів тощо).

Відзначимо, щзо норми Закону не містять положень щодо інших форм контрольної діяльності уповноважених суб'єктів: моніторингу, аудиту, нагляду, перевірки тощо. Відсутність засобів управлінської природи у спеціальному нормативно-правовому акті створюе ситуацію нівелювання окремих норм.

Прогалиною видається також відсутність норми, що встановлюе право громадських інспекторів здійснювати громадський контроль за законністю провадження аквакультури як самостійного виду сільськогосподарської діяльності, наприклад, здійснення громадського контролю щодо дотримання норм Зон аквакультури (рибництва) ma рибопродуктивності по регіонах України чи контроль за дотриманням законодавства суб'єктами аквакультури тощо.

Окрім здійснення контрольно-наглядової діяльності, також варто акцентувати увагу на здійсненні дозвільно-реєстраційної діяльності у сфері аквакультури уповноваженими суб'єктами.
Зокрема, цим Законом не урегульовано питання отримання дозволів (дозволу на спеціальне водокористування; дозволу на вилучення водних біоресурсів тощо) та здійснення реєстраційнӧ діяльності (об'єктів аквакультури, напрямів аквакультури тощо).

Запропоновано визначити шляхи реалізаціі залежно від статусу суб'єкта: а) для суб'єктів державного сектору; б) для суб'єктів приватного сектору; в) для експорту.

Окремим недоліком Закону хотілося б виокремити відсутність положень, що визначають взаємодію суб'єктів аквакультури між собою; взаємодію публічних органів управління та суб'єктів господарювання, які здійснюють аквакультуру; взаємодію між громадськими органами та органами публічного управління; взаємодію між громадськими органами та суб'єктами господарювання, які здійснюють аквакультуру.

Ключові слова: аквакультура, продукція аквакультури, правове регулювання, рибне господарство, рибництво.

Kozhura L. Features of legal regulation of aquaculture in Ukraine

This article reveals the features of the legal regulation of aquaculture.

It is emphasized that the Law of Ukraine "On Aquaculture" (hereinafter - the Law) does not contain provisions on the procedure for control and supervision. St. 16 of the Law is a blanket and refers to the Law of Ukraine "On Veterinary Medicine" on the procedure for veterinary and sanitary control. Instead, the Law itself does not provide for other types of control (for example, control over the submission of aquaculture entities reporting on the volume of aquaculture production; control over the activities of aquaculture entities during the breeding and/or cultivation of alien and non-native aquatic species, etc.). 
Note that the provisions of the Law do not contain provisions on other forms of control activities of authorized entities: monitoring, audit, supervision, inspections, etc.

The lack of means of administrative nature in a special legal act, create a situation of leveling certain rules. There is also a gap in the lack of a rule establishing the right of public inspectors to exercise public control over the legality of aquaculture as an independent agricultural activity, for example, public control over compliance with aquaculture (fisheries) and fish productivity in Ukraine or compliance with legislation by entities aquaculture, etc.

In addition, the implementation of control and supervision activities should also focus on the activities of authorized entities to carry out permitting and registration activities in the field of aquaculture. In particular, this Law does not regulate the issue of obtaining permits (permit for special water use; permit for extraction of aquatic bioresources, etc.) and registration activities (aquaculture facilities, aquaculture areas, etc.).

It is proposed to determine the ways of implementation depending on the status of the entity: a) for public sector entities; $b$ ) for private sector entities; $c$ ) for export.

A separate shortcoming of the Law would be to highlight the lack of provisions that determine the interaction of aquaculture entities with each other; interaction of public authorities and business entities engaged in aquaculture; interaction between public bodies and public administration bodies; interaction between public bodies and aquaculture entities.

Key words: aquaculture, aquaculture products, legal regulation, fisheries, fish farming.

\section{Література}

1. Аквакультура. Продовольственная и сельскохозяйственная организаиия Объединённых наций. URL: http:// wшw.fao.org / fishery / aquaculture / ru.

2. Про аквакультуру : Закон Украінни від 18 вересня 2012 року № 5293-VI. Відомості Верховної Ради, 2013. № 43. Cm. 616 .

3. Про рибне господарство, промислове рибальство та охорону водних біоресурсів : Закон України від 8 липня 2011 року № 3677-VI. Відомості Верховної Ради України, 2012. № 17. Ст. 155.

4. Водний кодекс України : Закон України від 6 червня 1995 року № 213/95-ВР. Відомості Верховної Ради України, 1995. № 24. Ст. 189.

5. Бойко О.В. Адміністративно-правове регулювання галузі рибного господарства України : дис. ... канд. юрид. наук : 12.00.07 «Адміністративне право i процес; фінансове право; інформаційне право». 2013. Запоріжжя, 227 с.

6. Борейко B.I. Аналіз стану рибного господарства України. / В.I. Борейко, Н.П. Павлюк. Вісник Національного університету водного господарства і природокористування. 2011. № 2(54). С. 17-22.

7. Вдовенко Н.М. Нормативно-правове регулювання господарської діяльності у сфері аквакультури. Економічний форум. 2014. № 4. C. 4-12. 